\title{
Influence of Peer Review on College ESL Writers
}

\author{
Irda Haryani Tahir \\ INTEC, Universiti Teknologi MARA, Shah Alam, 40200, Malaysia \\ irdah768@salam.uitm.edu.my
}

\begin{abstract}
Both students and teachers are environmentally challenged. Teachers are not well-heeled to do everything including giving feedback to students. Writing is a challenging area in teaching ESL. It was said that giving written feedback to students' writing is the most time consuming and challenging job (Ferris, 2007). This paper reports on a study designed to investigate and identify the benefits and the challenges of peer review, to investigate the influence of content and form based feedback to students writing. Teachers should be more aware of the right techniques to use in a writing class to produce allrounder future communities.
\end{abstract}

Keywords: Environmentally challenged, future communities, influence, peer evaluation.

eISSN 2398-4295 @ 2018. The Authors. Published for AMER ABRA cE-Bs by e-International Publishing House, Ltd., UK. This is an open-access article under the CC BY-NC-ND license (http://creativecommons.org/licenses/by$n c-n d / 4.0 /$ ). Peer-review under responsibility of AMER (Association of Malaysian Environment-Behaviour Researchers), ABRA (Association of Behavioural Researchers on Asians) and cE-Bs (Centre for EnvironmentBehaviour Studies), Faculty of Architecture, Planning \& Surveying, Universiti Teknologi MARA, Malaysia.

DOI: http://dx.doi.org/10.21834/ajbes.v3i9.67 


\subsection{Introduction}

Today's environment challenges students and teachers. With the advancement of technology, the students' attitudes and facilities available, students are becoming too dependent. Teachers will have to do almost everything and, with the burden of multitasking, teachers are not well off to do everything including giving feedback to students, especially their essays. Writing is a challenging area in teaching ESL. Ferris (2007) stated that teachers spend most time giving written feedback to students' writing, which is also the most crucial part of being a teacher. Therefore, through peer evaluation, teachers will have extra time and this extra time can be utilized to focus on teaching techniques rather than grading students' writing by themselves (Patri, 2002). The time saved can be used to help students refine their writing skills and also focus on other techniques of teaching. Students will also benefit from this to become more independent.

This research will be focusing on the issue discussed above and will be focusing on four main objectives. The objectives are students' perceptions on the benefits and its' challenges of peer evaluation, how content based feedback from peer evaluation influences students' writing and lastly how form based feedback from peer evaluation influences the students' writing.

\subsection{Literature Review}

Peer evaluation is one method that is essential in teaching writing. According to Sengupta (1998), the peer evaluation process involves students to write their own compositions that are their first draft. Then, they exchange this first draft with their partner or the person sitting next to them, read each other's work and give comments and suggestions where necessary. They then return the compositions with suggestions and comments. Peers then revise the essays and make improvements. The teachers' role here is just to facilitate where they need to guide the students and help out with difficult words and so on.

Peer evaluation helps students in certain ways especially in improving writing. In a study done by Roskam (1999), $70 \%$ of the students agreed that they learnt something from peer evaluation. Therefore, it is clear that peer evaluation helps improve writing through receiving suggestions from peers thus giving students awareness of their strength and weaknesses in writing, help improves both language and context of students' writing, add understanding of writing among students thus making students a more critical reader and writer.

Peer evaluation has been proven to help reduce teacher's workload. According to Patri (2002) and Hodges (2005), if peer evaluation can be done by students effectively, then teachers can reduce their workload and focus more on their teaching techniques. This way, teachers can teach more effectively as one of their workload has been reduced. They can finally focus and spend more time on teaching techniques for better and stimulating teaching and learning process in writing. Teachers will be able to spend more time focusing on teaching techniques rather than grading students' writing all by themselves. The time saved can be used to help students refine their writing. Peer evaluation helps teachers to focus on more helpful instructions and also to cut down teachers' marking duties to a minimum level. 
Communication and critical thinking can be gained through peer evaluation. Students need to communicate with their peers when doing peer evaluation. Peers comment and give suggestions and this helps students to gain and develop their social skills (Cheng and Warren, 1996 in Roskams, 1999). Through peer evaluation, students may increase their way of thinking in a variety of ways. Critical and order thinking may be improved due to evaluation done among peers (Todd \& Hudson, 2007). Furthermore, this way, they are more active than passive. This means, while conducting peer evaluation, it does not only improve writing, it improves communication and students' way of thinking at the same time.

However, there are still some drawbacks for peer review. What comes from students are not necessarily correct and precise. Moreover, students criticize their enemies, and they praise their friends and thus in effect tend to be bias. Woolhouse (1999) in Patri (2002) stated that students have difficulty in making sincere and truthful judgements. Oldfield and Macalpine (1995) in Patri (2002) mentioned that peers feel prejudiced emotionally against giving low grades to their classmates. They tend to help their friends by giving high marks. There are different levels of students and their responses may vary. During peer evaluation, students are said to overestimate and underestimate their peers. This was supported by Boud and Tyree (1979) in Patri (2002) who stated that peers tend to underestimate and overestimate their friends. Low achievers tend to overestimate high achievers and high achievers tend to underestimate low achievers.

Feedback should influence writing, and this varies according to the types of feedback. Content feedback might have its influences on students' writings. Sheppard (1992) mentioned that content based feedback is said to be better than form feedback (Guenette, 2007). Content based feedback is also said to be beneficial for the affective development from primary grades to university level though it does not focus on language form and structures (Fazio, 2001). On another aspect and view, content feedback is said to be just as effective if not more as feedback on form (Guenette, 2007). The effectiveness of both content based feedback, and the form based feedback are being debated and many have stated that both are equally prominent and have its own specialty.

\subsection{Methodology}

\subsection{Research subjects}

10 students from AUSMAT programme from INTEC, UiTM Shah Alam, were chosen to be the respondents and samples. As this research is a mix method research, these samples needed to go through two rounds of peer review sessions where the first step was content oriented peer review. Second step was self revision based from the feedback given by peers which was content based before the students have to come out with the second draft. Next stage was then form oriented peer review and then another self revision based from the feedback before the final draft. After this, they were to answer the questionnaire before the comments and revision analysis took place by the researcher. 


\subsection{Research instrument}

One of the data gathering instruments that were used in this research was students' feedback and revision analysis from the peer review sessions as comments, and the revision made by students were collected, coded, and analysed. This was done using forms and checklist as guidance (Bitchener, Young \& Cameron, 2005), students' feedback analysis (Analytic Model for Categorization of Comments by Wilson, 2002) as well as the revision analysis (Faigley \& Witte (1981). Another instrument used was a questionnaire adapted from McMurry (2004), Todd \& Hudson (2007) and Kwok (2008). All the feedbacks and data gathered were scrutinized to provide some insight into the issue of peer review, its benefits and challenges as well as the types of feedback and revision which are both in content and form.

\subsection{Findings and Analysis}

\subsection{Benefits of peer evaluation}

In Table 1, it is found that the highest benefit stated by the students was that they felt less pressure, and more relax when having peer review. This was supported by $70 \%$ of respondents who strongly agreed, and $30 \%$ who agreed. The same goes to $40 \%$ who strongly agreed and $60 \%$ who agreed that it was very easy to use the advice from their classmates to revise their essays. This was followed by $90 \%$ of the samples agreeing that their peer who peer reviewed their essays are nice. 30\% strongly agreed while $60 \%$ agreed and a total of $90 \%$ basically agreed that the advice they received are very useful. $10 \%$ of respondents strongly agreed and another $80 \%$ of respondents agreed that the evaluation and comments given were fair. $60 \%$ of the samples agreed that through peer review, they have the chance to do more practice and discussion. However, another $60 \%$ disagreed that the comments given are sufficient. Therefore, the benefits of peer review gained from this research are that students feel less pressured and more relaxed when doing peer review, the advice given by peers are easy to use to revise essay, their peers are nice, received useful advice, comments given are fair and through peer review, students are able to do more discussion and practices.

Table 1: Benefits Peer Review Questionnaire

\begin{tabular}{|c|c|c|c|c|c|c|c|c|}
\hline Statements & $\begin{array}{c}\text { SA } \\
\text { (Strongly } \\
\text { Agree) }\end{array}$ & $\%$ & $\begin{array}{c}\text { A } \\
\text { (Agree) }\end{array}$ & $\%$ & $\begin{array}{c}\text { D } \\
\text { (Disagree) }\end{array}$ & $\%$ & $\begin{array}{c}\text { SD } \\
\text { (Strongly } \\
\text { Disagree) }\end{array}$ & $\%$ \\
\hline $\begin{array}{c}\text { I think that the } \\
\text { evaluation and } \\
\text { comments } \\
\text { given are fair. }\end{array}$ & 1 & $10 \%$ & 8 & $80 \%$ & 1 & $10 \%$ & 0 & 0 \\
\hline $\begin{array}{c}\text { I think the } \\
\text { comments } \\
\text { given are useful } \\
\text { for making } \\
\text { improvement. }\end{array}$ & 2 & $20 \%$ & 8 & $80 \%$ & 0 & 0 & 0 & 0 \\
\hline I think that the & 1 & $10 \%$ & 3 & $30 \%$ & 6 & $60 \%$ & 0 & 0 \\
\hline
\end{tabular}


Tahir, I.H. / Asian Journal of Behavioural Studies (AjBeS), 3(9) Jan / Feb 2018 (p. 121-129)

\begin{tabular}{|c|c|c|c|c|c|c|c|c|}
\hline $\begin{array}{l}\text { comments } \\
\text { given are } \\
\text { sufficient. }\end{array}$ & & & & & & & & \\
\hline $\begin{array}{l}\text { I have more } \\
\text { chance to } \\
\text { practise and } \\
\text { discuss. }\end{array}$ & 1 & $10 \%$ & 5 & $50 \%$ & 4 & $40 \%$ & 0 & 0 \\
\hline $\begin{array}{l}\text { I felt less } \\
\text { pressure and } \\
\text { more relaxed. }\end{array}$ & 7 & $70 \%$ & 3 & $30 \%$ & 0 & 0 & 0 & 0 \\
\hline $\begin{array}{c}\text { My classmates } \\
\text { who review my } \\
\text { essays are very } \\
\text { nice. }\end{array}$ & 6 & $60 \%$ & 3 & $30 \%$ & 1 & $10 \%$ & 0 & 0 \\
\hline $\begin{array}{l}\text { The advice I } \\
\text { have received } \\
\text { from my } \\
\text { classmates are } \\
\text { very useful. }\end{array}$ & 3 & $30 \%$ & 6 & $60 \%$ & 1 & $10 \%$ & 0 & 0 \\
\hline $\begin{array}{l}\text { It was very } \\
\text { easy to use the } \\
\text { advice from my } \\
\text { classmates to } \\
\text { revise my } \\
\text { essays. }\end{array}$ & 4 & $40 \%$ & 6 & $60 \%$ & 0 & 0 & 0 & 0 \\
\hline
\end{tabular}

1.1. Challenges of peer evaluation

Table 2: Challenges Peer Review Questionnaire

\begin{tabular}{|c|c|c|c|c|c|c|c|c|}
\hline Statements & $\begin{array}{c}\text { SA } \\
\text { (Strongly } \\
\text { Agree) }\end{array}$ & $\%$ & $\begin{array}{c}\text { A } \\
\text { (Agree) }\end{array}$ & $\%$ & $\begin{array}{c}\text { D } \\
\text { (Disagree) }\end{array}$ & $\%$ & $\begin{array}{c}\text { SD } \\
\text { (Strongly } \\
\text { Disagree) }\end{array}$ & $\%$ \\
\hline $\begin{array}{c}\text { The quality of } \\
\text { comments given by } \\
\text { my peers is low. }\end{array}$ & 0 & 0 & 1 & $10 \%$ & 6 & $60 \%$ & 3 & $30 \%$ \\
\hline $\begin{array}{c}\text { The quality of } \\
\text { comments I give to my } \\
\text { peers is low. }\end{array}$ & 0 & 0 & 4 & $40 \%$ & 5 & $50 \%$ & 1 & $10 \%$ \\
\hline $\begin{array}{c}\text { My comments to my } \\
\text { peers are bias. }\end{array}$ & 1 & $10 \%$ & 1 & $10 \%$ & 7 & $70 \%$ & 1 & $10 \%$ \\
\hline $\begin{array}{c}\text { Comments given to } \\
\text { me are bias. }\end{array}$ & 0 & 0 & 1 & $10 \%$ & 8 & $80 \%$ & 1 & $10 \%$ \\
\hline $\begin{array}{c}\text { Peers tend to } \\
\text { overestimate me in my } \\
\text { writing. }\end{array}$ & 0 & 0 & 1 & $10 \%$ & 5 & $50 \%$ & 4 & $40 \%$ \\
\hline $\begin{array}{c}\text { Peers tend to } \\
\text { underestimate me in } \\
\text { my writing. }\end{array}$ & 1 & $10 \%$ & 0 & 0 & 8 & $80 \%$ & 1 & $10 \%$ \\
\hline $\begin{array}{c}\text { I tend to overestimate } \\
\text { my peers in their } \\
\text { writing. }\end{array}$ & 0 & 0 & 2 & $20 \%$ & 5 & $50 \%$ & 3 & $30 \%$ \\
\hline $\begin{array}{c}\text { I tend to } \\
\text { underestimate my }\end{array}$ & 0 & 0 & 1 & $10 \%$ & 5 & $50 \%$ & 4 & $40 \%$ \\
\hline
\end{tabular}


From Table 2, it can be concluded that the majority of the samples has less negative things to say about peer review. This was proven by firstly $40 \%$ of the respondents strongly disagreed, and $50 \%$ disagreed that peer underestimate them in their writing. Secondly, $40 \%$ of respondents strongly disagreed, and $50 \%$ disagreed that they tend to underestimate their friends' writing. This was followed by $30 \%$ of the samples strongly disagreed, and $60 \%$ disagreed that the quality of comments given was low. Moreover, $10 \%$ of the respondents strongly disagreed, and $80 \%$ of them disagreed that the comments given were bias. Another $10 \%$ of the samples strongly disagreed, and $70 \%$ of respondents disagreed that their comments to peers were bias. However, the only significant amount of challenges agreed by the students was the comments that were given by them to their peers were bias, but only by $40 \%$ as compared to $60 \%$ who disagreed. The challenges of peer review gained from this study are firstly the comments were not sufficient, which was gained from the benefit section which turned into negative. The rest of the points stated to be the challenges of peer review were not agreed by the respondents. The only point worth highlighting is that respondents were less confident about them giving comments to peers and were confident about their peers giving comments to them.

\subsection{Content based feedback influences on students' writing}

Table 3 illustrates that a number of $60 \%$ of respondents strongly agreed, and another $30 \%$ of respondents agreed that comments given by peers were beneficial for identifying errors in organization. $30 \%$ of the samples out of 10 students strongly agreed that comments by peers help them to identify errors in content, and ideas while another $40 \%$ of the samples agreed. $10 \%$ of respondents strongly agreed, and $80 \%$ of them agreed for both review to peers beneficial for peers' content and ideas, and own review beneficial for peers' organization. Looking at the percentages, it can be concluded that students are always more confident with what peers give rather than what they give to peers. It can be concluded that students are highly confident that peers' comments benefit most in improving grammar, the students' comments to peers are helpful in improving grammar and content and lastly, peers' comments benefit in improving the content of the essay.

Table 3: Content Oriented Questionnaire

\begin{tabular}{|c|c|c|c|c|c|c|c|c|}
\hline Statements & $\begin{array}{c}\text { SA } \\
\text { (Strongly } \\
\text { Agree) }\end{array}$ & $\%$ & $\begin{array}{c}\text { A } \\
\text { (Agree) }\end{array}$ & $\%$ & $\begin{array}{c}\text { D } \\
\text { (Disagree) }\end{array}$ & $\%$ & $\begin{array}{c}\text { SD } \\
\text { (Strongly } \\
\text { Disagree) }\end{array}$ & $\%$ \\
\hline $\begin{array}{c}\text { My reviews of } \\
\text { my peers' } \\
\text { papers were } \\
\text { beneficial for } \\
\text { identifying } \\
\text { errors in } \\
\text { content and } \\
\text { ideas. }\end{array}$ & 1 & $10 \%$ & 8 & $80 \%$ & 1 & $10 \%$ & 0 & 0 \\
\hline My reviews of & 1 & $10 \%$ & 8 & $80 \%$ & 1 & $10 \%$ & 0 & 0 \\
\hline
\end{tabular}




\begin{tabular}{|c|c|c|c|c|c|c|c|c|}
\hline $\begin{array}{c}\text { my peers' } \\
\text { papers were } \\
\text { beneficial for } \\
\text { identifying } \\
\text { errors in } \\
\text { organization. }\end{array}$ & & & & & & & & \\
\hline $\begin{array}{c}\text { Comments } \\
\text { provided by } \\
\text { my peer } \\
\text { papers were } \\
\text { beneficial to } \\
\text { me for } \\
\text { identifying } \\
\text { errors in } \\
\text { content and } \\
\text { ideas. }\end{array}$ & 3 & $30 \%$ & 4 & $40 \%$ & 2 & $20 \%$ & 1 & $10 \%$ \\
\hline $\begin{array}{c}\text { Comments } \\
\text { provided by } \\
\text { my peer } \\
\text { papers were } \\
\text { beneficial to } \\
\text { me for } \\
\text { identifying } \\
\text { errors in } \\
\text { organization. }\end{array}$ & 6 & $60 \%$ & 3 & $30 \%$ & 1 & $10 \%$ & 0 & 0 \\
\hline
\end{tabular}

From Table 4, there are two types of comments, which are the content and form based comments. The total of comments on content based is 73 which consumed $41 \%$. Content is less likely to be commented on during peer review as compared to form based feedback which consumed $59 \%$.

Table 4: Types of Comments Analysis

\begin{tabular}{|c|c|c|}
\hline Types of Comments & Frequencies & Percentage (\%) \\
\hline Content & 73 & $41 \%$ \\
\hline Form & 106 & $59 \%$ \\
\hline Total & 179 & $100 \%$ \\
\hline
\end{tabular}

\subsection{Form based feedback influences on students' writing}

From Table 5, it was found that all of the samples agreed that their reviews of peers' paper helped in identifying errors in spelling. 50\% strongly agreed while another $50 \%$ agreed. $40 \%$ of the students strongly agreed, and $50 \%$ agreed that their reviews of the peers' essay were beneficial in identifying grammar errors. 30\% strongly agreed and 50\% agreed that comments by peers were beneficial for identifying errors in spelling and the same goes also for grammar. Basically, students felt that their own comments to peers will help improve spelling and then grammar. This was followed by peers' comment were beneficial to improve spelling and then grammar. Here, students are more confident with what they comment on rather than their peers' comments. 
Table 5: Form Oriented Questionnaire

\begin{tabular}{|c|c|c|c|c|c|c|c|c|}
\hline Statements & $\begin{array}{c}\text { SA } \\
\text { (Strongly } \\
\text { Agree) }\end{array}$ & $\%$ & $\begin{array}{c}\text { A } \\
\text { (Agree) }\end{array}$ & $\%$ & $\begin{array}{c}\text { D } \\
\text { (Disagree) }\end{array}$ & $\%$ & $\begin{array}{c}\text { SD } \\
\text { (Strongly } \\
\text { Disagree) }\end{array}$ & $\%$ \\
\hline $\begin{array}{c}\text { My reviews of my } \\
\text { peers' papers were } \\
\text { beneficial for } \\
\text { identifying errors in } \\
\text { spelling. }\end{array}$ & 5 & $50 \%$ & 5 & $50 \%$ & 0 & 0 & 0 & 0 \\
\hline $\begin{array}{c}\text { My reviews of my } \\
\text { peers' papers were } \\
\text { beneficial for } \\
\text { identifying errors in } \\
\text { grammar. }\end{array}$ & 4 & $40 \%$ & 5 & $50 \%$ & 1 & $10 \%$ & 0 & 0 \\
\hline $\begin{array}{c}\text { Comments provided } \\
\text { by my peer papers } \\
\text { were beneficial to me } \\
\text { for identifying errors } \\
\text { in spelling. }\end{array}$ & 3 & $30 \%$ & 5 & $50 \%$ & 1 & $10 \%$ & 1 & $10 \%$ \\
\hline $\begin{array}{c}\text { Comments provided } \\
\text { by my peer papers } \\
\text { were beneficial to me } \\
\text { for identifying errors } \\
\text { in grammar. }\end{array}$ & 3 & $30 \%$ & 5 & $50 \%$ & 0 & 0 & 2 & $20 \%$ \\
\hline
\end{tabular}

\subsection{Conclusion}

Students feel less pressure and feel more relax when conducting peer review. Advices given by peers are useful and very easy to be used in revising essay. Through peer review, more practices and discussion are made among friends. Despite their peers being nice to them, the evaluation and comments given are fair. However, more than half of the respondents agreed that the comments given were insufficient. This has now become the biggest disadvantage of peer review in this research. The respondents disagreed that peers underestimated and overestimated the writings, bias and give low quality comments.

When comparing the two types of comments, it can be found that more comments are given for form rather than content. For content based feedback, it was found that students feel what they comment to their peers and what peers comment on them benefit in terms of grammar and also content of the writings. However, when asked about peers comments, the respondents seem more confident with peers' comments rather than with their own comments to peers. It can be concluded that the respondents were confident with what their friends commented on their writings, but they were not confident with what they did and commented on. Students are more of good evaluators but not good self-evaluators. For form based feedback, it was found that it benefits in terms of spelling and grammar. However, students are more confident with what they commented to their peers rather than what their peers commented on them. This is totally the opposite of content based feedback.

As this research has it's limitation which is the small sample of 10 students, it is recommended for future research to be done with larger sample and to investigate on the 
differences of comments as well as revisions from peer evaluation with the addition of proficiency. Through all prove to show improvements, the findings revealed that form based is preferred by students. From this study, teachers should be more aware of the right techniques to use in a writing class in order to inculcate better all-rounder students for future communities.

\section{References}

Bai, L., \& Nasu, S. (2017). CCRC Common Facility Spatial Structure: A Study by Space Syntax. Asian Journal of Environment-Behaviour Studies, 2(5), 1-13. doi:10.21834/aje-bs.v2i5.203 8AN

8AN

Martyn Descombe (2014). The Good Research Guide: For Small-Scale Social Research Projects. $5^{\text {th }}$ edition.

Open University Press, Berkshire, England.

8AN

Muhamad Solehin Fitry Rosley, Hasanuddin Lamit, Syumi Rafida (2017). Aesthetic and Perception: Indicators of perceiving the rural landscape. Asian Journal of Behavioural Studies 2(8), 11-22. doi: http://dx.doi.org/10.21834/ajbes.v2i6.31

$8 \mathrm{AN}$

Neo Sau Mei, Choong Weng Wai, Rahmalan Ahamad (2017). Public Environmental Awareness and Behaviour in Malaysia. Asian Journal of Quality of Life. doi: https://doi.org/10.21834/ajqol.v2i5.10

$8 \mathrm{AN}$

Singhirunnusorn, W., Donlakorn, K., \& Kaewhanin, W. (2017). Household Recycling Behaviours and Attitudes toward Waste Bank Project: Mahasarakham Municipality. Journal of ASIAN Behavioural Studies, 2(5), 17-26. doi:10.21834/jabs.v2i5.215

$8 \mathrm{AN}$

Triandriani Mustikawati, Yandi Andri Yatmo, Paramita Atmodiwirjo (2017). Understanding Wayfinding Experience of Hospital Visitor through Tours and Maps Analysis. Environment-Behaviour Proceedings Journal, 2(6), 149-157. https://doi.org/10.21834/e-bpj.v2i6.992 